\title{
Effects of property rights on agricultural production: The Nigerian experience
}

\author{
A. A. Akinola* and R. Adeyemo \\ Department of Agricultural Economics, Obafemi Awolowo University, Ile- Ife, Osun State, Nigeria.
}

30 Accepted July, 2013

\begin{abstract}
The study was conducted to examine the effects of property rights and other factors on the outputs of maize, yam and cassava in three zones of Osun State in Nigeria. This study employed a multi-stage sampling technique to select $\mathbf{1 0 5}$ farmers involving growers of maize, yam and cassava in the study area. Data were analyzed with the aid of descriptive statistics, budgetary techniques and a multiple linear regression model. The results of budgetary analysis showed that variable cost was highest in yam production. The average revenues per hectare for maize, yam and cassava were ( $\mathrm{N}$ is Nigerian currency equivalent to about \$0.0067) N104, 487.50, N583, 846.20 and N438, 208.50, respectively. However, the average net incomes were N19, 908.40, N432, 079.00 and N96, 543.90 for maize, yam and cassava, respectively. Based on the rates of returns, N1 invested in each of maize, yam and cassava production yielded N1.2, N3.4 and N3.1, respectively implying that yam was the most profitable crop in the study area. The result of the multiple regression model revealed that farm size significantly affect the outputs of the three crops. Land rights type (having either use right/use and transfer right) and security of land defined by duration of land use affected maize output while duration and ownership type affected yam output, whereas, duration only affect cassava output. There is therefore the need to review the land distribution and administration policies based on the identified significant factors affecting each crops.
\end{abstract}

Key words: Nigeria, Osun State, crops, maize, yam, cassava, land rights.

\section{INTRODUCTION}

Land is probably the most important factor of production. The unique feature of land is its fixed nature and this has generated a lot of policies administration in its use rights and transfer. The rights to land are an international issue with dynamisms depending on individual country's tenure arrangement. Property rights will determine land ownership related factors affecting the application of technologies for agricultural and natural resource management. Secured property rights give sufficient incentives to the farmers to increase their efficiencies in terms of productivity and ensure environmental sustainability. It is natural that without secured property rights, farmers do not feel emotional attachment to the land they cultivate, do not invest in land development and will not use inputs efficiently (Tenaw et al., 2009). There is broad agreement in the literature that secure individual land rights will increase incentives to undertake productivity enhancing land related investments. More secure property rights could affect productivity by improving household's security of tenure and thus their ability and readiness to make investments; providing better access to credit; and reducing the transaction 
costs associated with land transfers (Tenaw et al., 2009). Besley (1995) revealed that having more secure tenure to a plot increased the probability that individuals would plant trees, and undertake a wide range of other investments such as drainage, irrigation, mulching, etc. that would enhance better yield.

Fajemirokun (2000) indicated the need for secure ownership rights over a sufficiently long time horizon which needs not necessarily be a formal title to facilitate improvements emerges from most African countries.

\section{Land policies and reforms in Nigeria}

In Nigeria, reform has often sought to transform customary tenure land into state property or individualized private property. This was contained in the promulgation Land Use Act (LUA) of Nigeria, 1978. This brought about a fundamental change in land tenure systems through the abolition of private ownership of land (Fajemirokun, 2000). According to the Act, all land comprised in the territory of a State is vested in the State Governor who holds in trust for the use and common benefit of all Nigerians. Under this uniform system of land tenure, the highest interest in land is a right of occupancy. This can either be a statutory right of occupancy, which is granted by the State Governor in respect of land in both urban and non-urban areas and a customary right of occupancy, which is granted by a Local Government in respect of land in a non-urban area. Designation of urban and non-urban areas of a State is the exclusive responsibility of the State Government. During privatization, men (and particularly male heads of household) acquire complete and legal ownership of land (Davison, 1988). Individualized and private ownership transfers the few rights, such as cultivation rights, that women and minority groups may have land under customary rules to those men who are able to claim all rights to land (Lastarria-Cornhiel, 1997). More recently, there is the trend to recognize the previously existing customary tenure and land authorities which is still a problem to farmers especially the crop farmers. Rarely, however, has the effect of property rights on crops production been discussed in Nigeria and strong empirical evidence to test its effect and impact has been scarce and scattered due to paucity of literature. Several studies (Afeikhena, 2000; Besley, 1995; Feder et al., 1988) emphasized the effect of property rights on land conservation investment.

In Nigeria and other sub-Sahara countries, traditional land tenure system of ownership is still predominant. According to Deininger and Binswanger (1999), undefined property rights could affect economic growth in the following ways; Firstly, secure property rights will increase the incentives of households and individuals to invest, and often will provide them with better credit access, something that will not only help them make such investments, but will also provide and assurance substitute in the event of shocks. Secondly, it has long been known that in traditional agriculture, the operational distribution of land affects output, implying that a highly unequal land distribution will reduce productivity. Even though the ability to make productive use of land will depend on policies in areas beyond land policy that may warrant separate attention, secure and well-defined land rights are key for household asset ownership, productive development and factor market functioning. Based on the afore-mentioned assertions, the situation of land tenure system and property rights prevalent in most of developing countries in sub-Saharan Africa, Nigeria inclusive is similar in many respects as long as the agricultural production output remains low (Tenaw et al., 2009). They stressed that the changing climatic conditions in many developing countries have impacts on agricultural production at local and country level. This is an important issue, which is worth paying attention to in order to prevent problems that may affect the population. Insecure land right or the lack of land ownership also restricts the farmers' access to credit that are necessary for improved agricultural land practices for better yield (Feder et al., 1988). This non-access to credit predisposed farmers to go for traditional land-use practices which will eventually generate poor yield (Bamire and Fabiyi, 2002). The traditional institutions in the country allow various land acquisition types such as rent, share cropping and lease hold systems. These rights are non-definite, non-directional and insecure. There is therefore the need to get empirical evidence of the effects of land rights on crop outputs. Our study, therefore, intends to examine the socio-economic characteristics of the respondents; the nature, ownership and distribution of property rights in land and how they are acquired; determine the costs and returns to maize, yam and cocoa and also examine the effect of property rights on the output of these crops.

The importance of this study lies in providing information on the effect of property rights on crops output to assist policymakers where such rights are practiced in promoting right accessibility that would enhance better farmers yield.

\section{METHODOLOGY}

\section{Area of study}

The study was conducted in Osun state of Nigeria. Osun state is located in the south-western part of the country. It covers an area of approximately 14,875 square kilometers, with an estimated croppable land area of $8,822.55$ square kilometers. It shares common boundaries with Kwara, Ogun, Ekiti, Ondo and Oyo states. The indigenes of the state belong to the Yoruba tribe but nonindigene from all parts of Nigeria and foreigners also reside in the state. The major crops grown in the state are cassava, maize, vegetables, cocoa, oil palm, tomatoes etc. This implies that the climate in the state favours both arable and non-arable crops. The states experiences two major seasons, the dry and rainy seasons 
with August break during the rainy season. The annual temperature varies from 21.1 to $31.1^{\circ} \mathrm{C}$, while annual rainfall is within the range of $800 \mathrm{~mm}$ in the dry savannah agro-ecology to $1500 \mathrm{~mm}$ in the rain forest belt. Traditional land tenure arrangement is still predominant in the state. Rent, share cropping and short term lease arrangements which are often non-legal are popular in Nigeria and some West African Countries.

\section{Data and sampling technique}

A multi stage sampling technique was employed in selecting respondents for this study. In the first stage, Osun state was stratified into three based on the state's Agricultural Development Programme (ADP) classification, namely Ife/ljesha, Iwo Ikire and Osogbo zones. In the second stage, a local government area (LGA) was selected from each of the zones based on the predominance of agricultural practices. In the third stage, three villages were randomly selected from each of the LGA. In the final stage, a minimum of ten respondents were selected per villages. In all, 105 respondents were selected. Data were collected with the aid of structured questionnaire. Data were collected on the socioeconomic characteristics of the respondents such as sex, age, level of education and land factors and tenure arrangement such as land size, land ownership type, duration of tenure among others. Data collected were analyzed using the descriptive statistics, budgetary techniques and multiple linear regression technique. Descriptive statistics uses frequency count and percentage to describe the socio-economic variables of respondents in the study area. A total farm budget approach was undertaken to estimate costs and returns accruing to maize, yam and cocoa enterprises in the study area.

Since a budget is the quantitative expression of total farm plan summarizing the income, cost and profit -a residue of total cost from total revenue (Alimi and Manyong, 2002). Gross margin which is the difference between total revenue and total variable cost were analyzed. The total cost component is expressed as:

$\mathrm{TC}=\mathrm{TFC}+\mathrm{TVC}$

Where: TC $=$ Total cost TVC $=$ total variable cost TFC $=$ total fixed cost.

Gross margin $=(T R)-(V C)$

TVC $=$ TC - TFC

TFC $=$ TC - TVC

$\mathrm{TR}=$ Total revenue $=$ price $\times$ quantity that is, $\mathrm{PQ}$

$\mathrm{VC}=$ Variable cost

Profit $=$ TR - TC

Labour efficiency $=$ Total output/amount of labour used

The efficiency ratios that were analyzed were fixed cost ratios, variable to total cost ratio, labour efficiency amongst others. These were computed to indicate the performance of each of the enterprises. The data collected were analyzed using multiple linear regression models. This model was employed to examine the effects of socio-economic and land tenure factors on the outputs of maize, yam and cocoa. For each of the crops, the dependent variable of the regression model is the output $(\mathrm{kg})$. The postulated model assumed a relationship between the output of the crops and factors affecting crop output(s). The general empirical model is:

$\gamma=\alpha+\beta_{i} x_{i}$

Where ${ }^{\alpha}=$ constant /intercept; $\beta_{i}=$ coefficient of independent variables ${ }^{x_{i}}$.
The regression model for each of the production is modeled as:

$$
\begin{gathered}
\gamma=\alpha+\beta_{1} x_{1}+\beta_{2} x_{2}+\beta_{3} x_{3}+\beta_{4} x_{4}+\beta_{5} x_{5}+\beta_{6} x_{6}+\beta_{7} x_{7}+\beta_{8} x_{8}+\beta_{9} x_{9}+\beta_{10} x_{10} \\
+\mu
\end{gathered}
$$

Where $Y_{\mathrm{i}}$ is the quantity of individual crop produced in kilogram.

$x_{1}-x_{10}=$ explanatory variables

$\propto=$ constant (intercept)

The fitness of the model was based on the coefficient of multiple determinations $\left(R^{2}\right)$, adjusted $R^{2}$ and significance of regression coefficient at a specific level (1, 5 or $10 \%)$.

$x_{1}=$ Age of the respondent (AGERES) in years

$x_{2}=$ Marital status (MARISTAT); ( 1 if married and 0 otherwise)

$x_{3}=$ Farming experience (FARMEXP) in year

$x_{4}=$ Household size (HHSIZE)

$X_{5}=$ Duration of land use (DURLNDU) in years

$x_{6}=$ Land right type (RIGHTYP); (use right only = 0; use and transfer right $=0$ )

$x_{7}=$ Land ownership type (LNDOWSIP); 1 if owned and 2 otherwise

$x_{8}=$ Total farm size (FARMSIZ) in hectare

$x_{9}=$ Level of education (LEVEDU) in years

$x_{10}=$ Extension visit $(E X T V I T) ; 1$ if visited and 0 otherwise

$\mu \mathrm{i}=$ error term

\section{A priori expectation signs of the coefficients}

The multiple independent variables included socio-economic and tenural factors that may influence crop output. These variables include age (AGE) of respondents in years, marital status (MARISTAT), farming experience (FARMEXP), household size (HHSIZE), duration of land use (DURLNDU), land rights type (RIGHTYP), land ownership type (LNDOWSIP), farm size (FARMSIZ), level of education (LEVEDU) and extension visit (EXTVIT). The rationale for inclusion of these variables was based on a priori expectation of factors influencing agricultural output. The effect of age (AGERES) on the output may be positive or negative. Previous study shows that the age of individuals affects their output in several ways. Younger farmers have been found to be more agile and would be ready to take on new practices that could improve crop yield. The older the farmer, the less likely may be his output from crops (Amos, 2007). Marital status (MARISTAT) of respondents may have influence on respondents output positively. It is expected that the married individuals have greater number of labour which may increase output. Farming experience is a measure of the number of years a respondent has farmed. We hypothesized that farming experience will positively influence farmers output. It is expected that the more the experience, the greater the resource use and hence the better the output (Amos, 2007; Akinola and Adeyemo, 2008).

Household size (HHSIZE) determines the supplementary man days' of labour that could be produced by the family (Amos, 2007; Yang and Zhang, 1999). We then hypothesized that household with larger size have higher probabilities to acquire more output than smaller household size because the larger the household size, the greater the man power, hence, more labour to work on the farm. Duration of use (DURLNDU) of land is a measure of the length in years that the land would be used. The longer the time period the greater the likelihood those farmers would adopt soil enhancing technology that would increase crop yield (Tenaw et al., 2009). It is expected that the longer the length of use, the greater the tendency that the land occupiers owns to land and the greater the probability of investing in land enhancing technology that would enhance greater (Ogedengbe and Akinbile, 2004). The type of right (RIGHTYP) 
individual is having over a parcel of land may have positive or negative influence on production. Individual with use right only may not adopt land improving technology and hence, low output while individual with both use and transfer right can adopt new and hence, greater output (Ogedengbe and Akinbile, 2004; Clay, 2008). The Ownership type (LNDOWSIP) defined the land ownership type, which is whether land is owned or otherwise. It is expected that ownership type will influence the rights to hold a parcel of land because the more your income the larger the amount of land you can purchase (Clay, 2008).

Farm size (FARMSIZE), the total farm size owned by respondents is expected to positively influence crop output. The larger the farm size owned, the greater the area that will be put under cultivation and the more the expected output (Clay, 2008). Level of education (LEVEDU) is expected to positively influence crop output. Extension visit (EXTVIT): It is hypothesized that the greater the land allocated for permanent crops, the greater the output from permanent and the less the available land for arable and hence, the lower the yield from arable.

\section{RESULTS AND DISCUSSION}

\section{Socio-economic characteristics of respondents}

Table 1 showed the socio-economic characteristics of the respondents. The analysis revealed that $75.2 \%$ of the respondents were male while 24.8 were female. This implies that farming in the study area were male dominant. The analysis further showed that $57 \%$ of the respondents fell between the ages of 41 to 50 years, while about $28.6 \%$ of the respondents have age of 51 years and above. This implies that most of the farmers in the study area are still in their active age. The farmers in the area are experience. Analysis revealed that 57 and $22 \%$ of the respondents were having 5 to 10 years and 11 to 15 years of experience, respectively. On the duration of land use, $66.7 \%$ of the respondents has maximum of 5 years of duration, while just about $33.32 \%$ has 6 years duration and above. This implies that the farmers in the area will be reluctant to adopt soil enhancing technology that would improve crop yield. Also, 63.8 and $36.2 \%$ of the respondents indicated that they have use rights and transfer rights, respectively. Majority of the respondents $(62.9 \%)$ do not own land while just $37.1 \%$ of the respondents owned land. Majority of the respondents are relatively educated. 39.4 and $48.8 \%$ of the respondents finished from primary and secondary schools, respectively. The respondents in the area do not have access to extension service. Analysis revealed $93.3 \%$ of the respondents indicated that they do not have access to extension services.

\section{Budgetary analysis for maize, yam and cassava}

Results of the budgetary analysis revealed that the average gross revenue for maize, yam and cassava were N104, 875, N583, 846.2 and N438, 208.5, respectively (Table 2). The average variable costs incurred in maize, yam and cassava were N43,814.9, N107, 414.9 and
N96, 543.9, respectively. The higher cost incurred in yam may probably due to extra cultural practices like staking and mulching involved in yam production. Gross margin values were $\mathrm{N} 60,672.6, \mathrm{~N} 476,431$ and $\mathrm{N} 341,664.1$ ( $\mathrm{N}$ is Nigerian currency equivalent to about $\$ 0.0067$ ) for maize, yam and cassava, respectively. The rate of returns for maize, yam and cassava were 1.2, 3.4 and 3.1, respectively (Table 3 ). This implies a better viability of yam enterprise in the study area.

\section{The multiple linear regression result}

The results of the multiple linear regressions shown in Tables 4,5 and 6 revealed that $R$-square values for maize, yam and cassava were $79.6,70.7$ and $86.6 \%$, respectively, while the adjusted R-squared were 68.3 , 56.3 and 76.2 , respectively. This implies that $68.3,56.3$ and $76.2 \%$ changes in the outputs of maize, yam and cassava were accounted for by the independent variable. The result (Table 4) showed that household size, right type, ownership type, total farm size used for farming and level of education were statistically significant affect the output of maize at $10,10,10,1$ and $5 \%$, respectively. This implies that household size, right type, ownership type, total farm size used for farming and level of education were significant determinants of maize production in the study area. The significance of rights type and ownership type indicated the land tenure arrangements (rights) have significant effects in maize production in the area. The result of Table 5 revealed that farming experience, duration of land use, ownership type and total farm size were significant determinants of output of yam in the area. They were significant at 10, 10, 5 and $10 \%$, respectively. This implies that the greater the duration a plot of land, the greater the tendency that farmers output will increase. Also, those who owned land will have better output as the will be willing to adopt output enhancing technology. The result of Table 6 revealed that duration of land use, total farm size and level of education were significant determinants of output of cassava in the area. They were significant at 5, 1 and $5 \%$, respectively. This implies that the greater the duration a plot of land, the greater the tendency that farmers output will increase because he will be willing to adopt output enhancing technologies.

Also, those with larger farm size will have better output as they will enjoy economics of large scale production. It could be seen that land rights have significant effects on the outputs of crops in the study area.

\section{Conclusion}

Farmers in the study area were mostly married, middle aged with majority having formal education. The analysis revealed that farming activities in the study area is male dominant as $75.2 \%$ of the respondents were male while 
Table 1. Socio-economic, demographic and farm characteristics of respondents.

\begin{tabular}{|c|c|c|}
\hline Variable & Frequency & Percentage \\
\hline \multicolumn{3}{|l|}{ Sex } \\
\hline Male & 79 & 75.2 \\
\hline Female & 26 & 24.8 \\
\hline Total & 105 & 100 \\
\hline \multicolumn{3}{|l|}{ Age } \\
\hline$\leq 30$ & 7 & 6.7 \\
\hline $31-40$ & 11 & 10.5 \\
\hline $41-50$ & 57 & 54.3 \\
\hline $51-60$ & 13 & 12.4 \\
\hline$>60$ & 17 & 16.2 \\
\hline \multicolumn{3}{|l|}{ Marital status } \\
\hline Single & 11 & 10.5 \\
\hline Married & 78 & 74.3 \\
\hline Others & 16 & 15.2 \\
\hline Total & 105 & 100 \\
\hline \multicolumn{3}{|l|}{ Level of experience } \\
\hline$<517$ & 16.2 & \\
\hline $5-1057$ & 54.3 & \\
\hline $11-1522$ & 21 & \\
\hline 16 and above 9 & 8.6 & \\
\hline Total & 105 & 100 \\
\hline \multicolumn{3}{|l|}{ Household size } \\
\hline $1-2$ & 43 & 41 \\
\hline $3-4$ & 41 & 39.5 \\
\hline $5-6$ & 9 & 8.6 \\
\hline 7-9 & 8 & 7.6 \\
\hline 10 and above & 4 & 3.8 \\
\hline Total & 105 & 100 \\
\hline \multicolumn{3}{|c|}{ Duration of land use in years } \\
\hline$<2$ & 23 & 21.9 \\
\hline $3-5$ & 47 & 44.8 \\
\hline $6-8$ & 8 & 7.62 \\
\hline$>8$ & 27 & 25.7 \\
\hline Total & 105 & 100 \\
\hline \multicolumn{3}{|l|}{ Right type } \\
\hline Use right only & 67 & 63.8 \\
\hline Use and transfer right & 38 & 36.2 \\
\hline \multicolumn{3}{|l|}{ Land ownership } \\
\hline Owned & 39 & 37.1 \\
\hline Otherwise & 66 & 62.9 \\
\hline Total & 105 & 100 \\
\hline \multicolumn{3}{|l|}{ Farm size } \\
\hline$<1$ & 67 & 63.8 \\
\hline $1.1-2.0$ & 19 & 18.1 \\
\hline $2.1-3.0$ & 11 & 10.5 \\
\hline 3.1 and above & 8 & 7.6 \\
\hline
\end{tabular}


Table 1. Contd.

\begin{tabular}{lcc}
\hline Total & 105 & 100 \\
Level of education & & \\
None & 11 & 10.5 \\
Primary & 41 & 39.4 \\
Secondary & 46 & 48.8 \\
Tertiary & 7 & 6.7 \\
Total & & 105 \\
Extension visit & & \\
None & 98 & 93.3 \\
Regular & 1 & 0.95 \\
Occasional & 6 & 5.7 \\
Total & 105 & 100 \\
\hline
\end{tabular}

Source: Field survey (2011).

Table 2. Budgetary analysis for maize, cassava and cassava enterprises.

\begin{tabular}{lccc}
\hline Items & Maize & Yam & Cassava \\
\hline (A) Gross revenue $(\mathbb{N})$ & $204,487.5$ & $583,846.2$ & $438,208.5$ \\
(B) Variable cost $(\mathbb{A})$ & & & \\
Land clearing & 15041.5 & $22,041.5$ & $21,220.5$ \\
Labor (harrowing, ridging) & $15,857.9$ & 49357.1 & $44,543.8$ \\
Weeding & $19,551.8$ & 23951.8 & $21,320.5$ \\
Harvesting & $5,364.5$ & $11,064.5$ & $6,006.7$ \\
Haulage & $3,000.1$ & 4,000 & $3,452.4$ \\
Planting material & $12,470.4$ & $13,670.9$ & $11,665.8$ \\
Total variable cost $(\mathbb{N})$ & $66,284.3$ & $114,085.8$ & $96,543.9$ \\
(C) Fixed cost $(\mathbb{N})$ & & & \\
Rent & $28,681.7$ & $30,681.3$ & $31,223.5$ \\
(D) Total fixed cost $(\mathbb{N})$ & $41,151.7$ & $44,351.7$ & $42,889.3$ \\
E) Total cost $(\mathrm{B}+\mathrm{C})(\mathrm{N})$ & $84,966.6$ & 151,766 & $139,433.2$ \\
(F) Net farm income $(\mathrm{N})$ & $119,908.4$ & 432,079 & $298,775.3$ \\
\hline
\end{tabular}

Source: Field survey (2011).

Table 3. Profitability and efficiency measures for maize, cassava and cocoa enterprise.

\begin{tabular}{lccc}
\hline Description & Maize & Yam & Cassava \\
\hline Profit $(\mathbb{N})$ & $19,908.4$ & 432,079 & $298,775.3$ \\
Gross margin $(\mathrm{GM})(\mathrm{N})$ & $60,672.6$ & 476,431 & $341,664.6$ \\
Rate of return $(\mathbb{N})$ & 1.2 & 3.4 & 3.1 \\
Cost ratio & 1.1 & 2.4 & 2.2 \\
\hline
\end{tabular}

just $24.8 \%$ farmers in the area are well experienced. Analysis revealed that 57 and $22 \%$ of the respondents were having 5 to 10 and 11 to 15 years of experience, respectively. Majority has short duration of land use. About $66.7 \%$ of the respondents has maximum of 5 years of duration, while just about $33.32 \%$ has 6 years duration and above. Also, 63.8 and $36.2 \%$ of the respondents indicated that they have use rights and transfer rights, respectively. Majority of the respondents $(62.9 \%)$ do not own land while just $37.1 \%$ owned land. Budgetary analysis 
Table 4. Result for linear regression for production of maize.

\begin{tabular}{llll}
\hline Variable & Coefficients & Standard error & T-ratio \\
\hline Age & 116.261 & 241.887 & 0.762 \\
Marital status & -942.137 & 1684.930 & 0.481 \\
Farming experience & 35.15 & 148.832 & 0.236 \\
Household size & -2254.999 & 1078.482 & $-2.091^{*}$ \\
Duration of land use & -4080.7087 & 3375.907 & -1.209 \\
Right type & 16139.234 & 8491.657 & $1.901^{*}$ \\
Ownership type & 3928.653 & 2025.114 & $1.940^{*}$ \\
Total farm size & 1799.067 & 325.348 & $5.530^{\star * *}$ \\
Level of education & 1388.818 & 443.899 & $3.129^{\star *}$ \\
Extension visit & -440.207 & 668.776 & -0.658 \\
Constant & 9703.072 & 12737.720 & 0.762 \\
\hline
\end{tabular}

${ }^{* * *}=$ significant at $1 \%,{ }^{* *}=$ significant at $5 \%$ and ${ }^{*}=$ significant at $10 \%, \mathrm{R}$ square 79.6 ; adjusted $\mathrm{R}$ square 68.3 . Sources: Survey data (2011).

Table 5. Result for linear regression for production of yam.

\begin{tabular}{lccc}
\hline Variable & Coefficients & Standard error & T-ratio \\
\hline Age & -68.841 & 271.870 & -0.253 \\
Marital status & 629.863 & 1659.655 & .380 \\
Farming experience & 290.228 & 139.932 & $2.074^{\star}$ \\
Household size & -1938.522 & 1159.615 & -1.672 \\
Duration of land use & 7006.879 & 3752.936 & $1.867^{\star}$ \\
Right type & -6450.729 & 8504.342 & -0.759 \\
Ownership type & 3285.376 & 2337.540 & $1.405^{\star \star}$ \\
Total farm size & 549.199 & 300.935 & $1.825^{\star}$ \\
Level of education & 195.062 & 418.985 & 0.466 \\
Extension visit & -581.645 & 600.349 & -0.969 \\
Constant & 24049.714 & 13769.053 & 1.747 \\
\hline
\end{tabular}

*= significant at 10\%, R square 70.7; Adjusted R square 56.3. Sources: Survey data (2011).

Table 6. Result for linear regression for production of cassava.

\begin{tabular}{lccc}
\hline Variable & Coefficients & Standard error & T-ratio \\
\hline Age & 101.163 & 228.776 & 0.442 \\
Marital status & -1571.179 & 1552.849 & -1.012 \\
Farming experience & -171.979 & 145.846 & -1.179 \\
Household size & -1254.575 & 1048.515 & -1.197 \\
Duration of land use & 8194.197 & 3005.352 & $2.727^{* *}$ \\
Right type & -7248.648 & 10502.295 & -0.690 \\
Ownership type & -352.914 & 2151.264 & -0.164 \\
Total farm size & 1634.392 & 297.457 & $5.495^{* * *}$ \\
Level of education & 1085.750 & 406.419 & $2.672^{* *}$ \\
Extension & -544.257 & 691.718 & -0.787 \\
Constant & 31171.665 & 13209.550 & 2.360 \\
\hline
\end{tabular}

${ }^{* * *}=$ significant at $1 \%,{ }^{* *}=$ significant at $5 \%, \mathrm{R}$ square 86.6 ; Adjusted $\mathrm{R}$ square 76.2 . Sources: Survey data (2011).

revealed highest values of gross margin and net income were recorded for yam compared to other enterprises.
The average total revenue for yam, cassava and maize were $583,846.2,438,208.5$ and 104,875 , respectively. 
The average total cost incurred in yam, cassava and maize enterprises were 151,766, 139,433.2 and $84,966.6$, respectively. The rate of returns to investments for yam, cassava and maize were 3.4, 3.1 and 1.2, respectively. The result of the multiple linear regression model and its implications revealed that household size, right type, ownership type, farm size and level of education significantly influence maize output. This implies that farmers with defined rights and owned land would have better output. The analysis further revealed that farming experience, duration of land use and ownership also affects yam output. This implies that farmers that owned land can adopt output enhancing technology than those who rent or engage in share cropping. Regression analysis on the factors influencing maize cassava output revealed that duration of land use, farm size and level of education significantly affect cassava output. This implies that the longer the duration, the larger the size and the more educated a farmer is, the greater the output. Therefore, government at all levels and her agencies should put machineries in place that would formulate policies and programmes that would enhance land distribution and ownership in this part of the country and in other regions where the same practices operate.

\section{REFERENCES}

Afeikhena J (2000). Land Rights and Investment Incentives in Western Nigeria A paper Presentated at the Beijer Research Seminar on Property Rights Structures and Environmental Management, South Africa.

Akinola AA, Adeyemo R (2008). Adoption and Productivity of Improved Rice Varieties in Osun State, Nigeria”. Ife J. Agric. 23(1):104-116.
Alimi T, Manyong VM (2000). Partial Budget Analysis for on-farm Research.

Amos TT (2007). Resource Use in Tilapia production among Small Scale Tilapia Farmers in the Savanna Zone of Northern Nigeria. J. Fish. Int. 2(1):42-47. (missing the dot)

Bamire AS, Fabiyi YL (2002). Adoption pattern of fertilizer technology among farmers in the ecological zones of South-Western Nigeria: A Tobit analysis. Aust. J. Agric. Res. 53:901-910.

Besley T (1995). Property Rights and Investment Incentives: Theory and Evidence from Ghana. J. Polit. Econ. 103(5):903-937.

Clay K (2008). Property Rights and Agricultural Production. H. John Heinz III School of Public Policy and Management Carnegie Mellon University Pittsburgh.

Davison J (1988). "Agriculture, Women, and Land" The African Experience. Boulder, Colorado (USA): (ed.) West view Press. pp. 7475.

Deininger K, Binswanger H (1999). "The Evolution of the World Bank's and Land policy: Principles, Experience and future challenges. World Bank Res. Obser. 14:247- 276.

Fajemirokun B (2000). Land and Resource Rights: Issues of Public Participation And Access to Land in Nigeria. Potential decentralization models are discussed in C. Toulmin, "Decentralization and Land Tenure" in C. Toulmin \& J. Quan (eds.), Evolving Land Rights, Policy and Tenure in Africa, (London,). pp. 229-245.

Feder G, Ohdaan T, Chalaniwong Y, Hongladaron C (1988). "Land Policy and Farm Productivity in Thailand". Baltimore: Johns Hopkins University press.

Lastarria-Cornhiel S (1997). "Impact of Privatization on Gender and Property Rights in Africa". World Dev. 25(8):1317-1333.

Ogedengbe K, Akinbile CO (2004). Determination of Consumptive Water Use of Corchorus oliforius (ewedu) Using Blaney-Morin Simulation Model. J. Sci. Eng. Technol. 11(3):5653-5663.

Tenaw SKM, Zahidul I, Parviainen T (2009). Effects of land tenure and property rights on agricultural productivity in Ethiopia, Namibia and Bangladesh. University of Helsinki Department of Economics and Management Discussion Papers no 33 Helsinki 2009. 